Original Research Paper

\title{
Pengembangan Potensi Eduwisata Melalui Tata Kelola Sumber Daya Alam Dan Lingkungan Di Desa Padamara Kecamatan Sukamulia Kabupaten Lombok Timur, NTB
}

\author{
Lalu Ali Wardana ${ }^{1}$, Muhammad Hasyatillah ${ }^{2}$, Ega Sulastri ${ }^{3}$, Dina Ardina Sari ${ }^{3}$, Hilyana Zilfit ${ }^{3}$, Rizka \\ Azzahral Fanani ${ }^{4}$, Winda Artani ${ }^{5}$, Maksum Roby Yahya ${ }^{6}$ \\ ${ }^{\text {I}}$ Fakultas Keguruan dan Ilmu Prndidikan, Universitas Mataram, Mataram Indonesia \\ ${ }^{2}$ Fakultas Hukum, Universitas Mataram, Mataram Indonesia \\ ${ }^{3}$ Fakultas Keguruan dan IlmuPendidikan, Universitas Mataram, Mataram Indonesia \\ ${ }^{4}$ Fakultas MIPA, Universitas Mataram, Mataram Indonesia \\ ${ }^{5}$ Fakultas Teknologi Pangan dan Agroindustri, Universitas Mataram, Mataram Indonesia \\ ${ }^{6}$ Fakultas Ilmu Sosial dan Politik, Universitas Mataram, Mataram Indonesia
}

DOI: https://doi.org/10.29303/jpmpi.v4i2.849

Sitasi: Wardana. L. A., Hasyatillah, M., Sulastri, E., Sari, D. A., Zilfit, H., Fanani, R. A., Artani, W., \& Yahya, M. R. (2021). Pengembangan Potensi Eduwisata Melalui Tata Kelola Sumber Daya Alam Dan Lingkungan Di Desa Padamara Kecamatan Sukamulia Kabupaten Lombok Timur, NTB. Jurnal Pengabdian Magister Pendidikan IPA, 4(2)

\section{Article history}

Received: 30 April 2021

Revised: 23 Mei 2021

Accepted: 30 Juni 2021

*Corresponding Author: Lalu Ali wardana, Fakultas

Keguruan dan Ilmu Pendidikan, Universitas Mataram, Mataram Indonesia

Email:

Aliwardana@unram.ac.id

\begin{abstract}
Indonesia adalah negara kepulauan yang memiliki potensi besar untuk pengembangan eduwisata. Desa Padamara adalah salah satu dari 9 yang ada di Kecamatan Sukamulia, dengan luas 195 Ha dan memiliki 5 dusun. Keindahan alam Desa Padamara sepanjang jalannya dihiasi oleh indahnya hamparan sawah dan sedikit taman jati. Taman jati di Desa Padamara memiliki potensi yang sangat baik jika dikembangkan menjadi wisata edukasi dengan menampilkan keindahan alam dan mengutamakan kebersihan lingkungan sehingga dapat memberikan manfaat dari segi ekonomis dan nilai estetis lingkungan. Tujuan pengabdian ini ialah terciptanya nilai keindahan alam dan nilai ekonomi sehingga tercipta desa eduwisata Padamara. Metode yang digunakan dalam pengabdian ini yaitu berupa simulasi, praktik dan pedampingan yang dilaksanakan selama 45 Hari. Hasil pengembangan dicapai adalah terbentuknya program eduwisata seperti pembentukan taman baca, wisata taman jati, serta kelas inspirasi. Program tersebut menghasilkan dampak positif yaitu meningkatnya kualitas sumber daya manusia dan ekonomi masyarakat yang ada di Desa Padamara. Dengan adanya program-program tersebut diharapkan masyarakat mendapatkan pengetahuan dan wawasan sehingga dapat dimanfaatkan dalam kehidupan sehari-hari dilingkungan masyarakat desa.
\end{abstract}

Keywords: Eduwisata, Taman Jati dan pemberdayaan ekonomi

\section{Pendahuluan}

Indonesia adalah negara yang diakui dunia sebagai negara kepulauan sebagaimana yang dimuat dalam (UNCLOS, 1982) yag dikutip oleh (Lasabuda, 2013). Sebagai Negara kepulauan yang penduduknya terdiri dari berbagai macam ras, suku agama dan budaya yang berbeda-beda, setiap daerah mempunyai keunikan dan keunggulan masing-masing dimana salah satunya adalah termasuk potensi alamnya (Lestari, 2015). Hal ini menjadi sebuah keuntungan terutama dalam bidang kepariwisataan. Banyaknya potensi yang dimiliki baik dari potensi alam maupun masyarakatnya tentu akan menarik wisatawan untuk berkunjung ke 
Indonesia dan akan memberikan keuntungan bagi negara maupun daerah tersebut (Hijrriati dan Rina, 2014). Dari berbagai wilayah yang ada di Indonesia Lombok merupakan pulau dengan keindahan alam yang sangat luar biasa.

Provinsi Nusa Tenggara Barat merupakan daerah yang memiliki potensi budaya dan alam yang sangat menunjang perkembangan wilayah berbasis pada pariwisata. Desa wisata yang sangat populer sebagai objek wisata di NTB yaitu Desa Wisata Sukarara dan Desa Wisata Rembitan. Kedua desa ini terletak di Kabupaten Lombok Tengah. Sementara itu, Lombok Timur juga memiliki Desa Wisata yang tidak kalah indahnya yaitu Desa Wisata Sembalun Bumbung, Desa Wisata Sembalun Lawang yang keduanya terletak di sebelah timur Rinjani, Gili Lampu, Pantai Sorga dan masih banyak lagi (Permadi et al., 2018).

Desa Padamara adalah satu dari (9) desa yang ada di kecamatan Sukamulia, dan merupakan desa dengan luas $195 \mathrm{Ha}$. Desa Padamara terdiri dari 5 dusun, yakni Dayen Rurung, Timuq Rurung, Lauq Rurung, Dasan Tangar, dan Dasan Baru. Desa ini memiliki area persawahan disepanjang jalan yang menampilkan keindahan alam yang sangat berpotensi untuk dikembangkan menjadi eduwisata. Selain itu, ternak sapi menjadi daya tarik tersendiri bagi para pengunjung untuk medapatkan penjelasan bagaimana beternak sapi yang baik.

Jumlah penduduk seluruhnya di Desa Padamara adalah 4.321 jiwa dengan jumlah penduduk masing-masing dusun yakni, Dusun Dayan Rurung dengan jumlah 1.059 jiwa, Dusun Lauq Rurung 809 jiwa, Dusun Timuq Rurung 635 jiwa, Dusun Dasan Tangar 874 jiwa, dan Dusun Baru dengan 944 jiwa. Penduduk laki-laki di Dusun Dayan Rurung berjumlah 521 orang, Dusun Lauq Rurung berjumah 384 orang, Dusun Timuq Rurung 304 orang, Dusun Dasan Tangar 432 orang, dan Dusun Dasan Baru 469 orang. Sehingga jumlah total penduduk laki-laki di Desa Padamara adalah 2.101 orang. Penduduk perempuan di Dusun Dayan Rurung sebanyak 538 orang, Dusun Lauq Rurung sebanyak 425 orang, Dusun Timuq Rurung sebanyak 331 orang, Dusun DasanTangar 451 orang, dan Dusun Dasan Baru 475 orang. Total jumlah penduduk perempuan di Desa Padamara adalah 2.220 orang. Jumlah kepala keluarga di Dusun Dayan Rurung sebanyak 310 kepala keluarga (KK), Dusun Lauq Rurung 277 (KK), Dusun Timuq Rurung 197 KK, Dusun Dasan
Tangar 301 KK, dan Dusun Dasan Baru sebanyak 291 KK, sehingga total kepala keluarga di Desa Padamara yaitu 1.376 KK. Sedangkan jumlah penduduk miskin $415 \mathrm{KK}$.

Secara umum mata pencaharian penduduk di Desa Padamara terdiri dari petani sebanyak 1.180 orang, buruh tani sebanyak 1.027 orang, pedagang sebanyak 110 orang, PNS/TNI/Polri sebanyak 101 orang, Sopir sebanyak 25 orang, karyawan swasta sebanyak 105 orang, tukang kayu/tukang batu 50 orang, pengrajin sebanyak 66 orang, Guru 45 orang, dan lain-lain 22 orang. Dari data isian profil desa Padamara, pada bidang pertanian jenis tanaman yang banyak ditanam oleh penduduk desa Padamara adalah padi, jagung, tomat, cabai, ubi, kacang tanah, dan kacang kedelai. Sedangkan pada bidang peternakan, penduduk desa Padamara banyak beternak sapi, kuda, kambing/domba, ayam, angsa, dan itik. Pada bidang komoditi perkebunan dan buah-buahan, tanaman perkebunan di desa Padamara adalah kelapa, tembakau Virginia, tembakau Rakyat, sedangkan tanaman buah-buahan yang ada di desa Padamara adalah mangga dan pisang.

Dari sekian jumlah penduduk Desa Padamara sebagian besar tingkat pendidikannya cukup rendah, hal ini terbukti dari jumlah penduduk yang memiliki pekerjaan sebagai petani dan buruh tani yang lebih dominan selain karena potensi/kekayaan alam yang ada di desa Padamara berupa lahan pertanian, namun pendidikan dalam meningkatkan sumber daya manusia juga sangat penting dan masih banyak masyarakat yang belum memiliki pekerjaan tetap selain bertani dan beternak. Perlunya pengembangan sumber daya manusia untuk mempersiapkan masyarakat secara optimal melalui program pendidikan dan program tambahan. Masyarakat yang masih kurang mengetahui tentang bagaimana mengolah hasil tani dan cara berternak yang menghasilkan hasil pertanian dan perternakan yang bernilai jual tinggi. Sehingga diperlukannya inovasi-inovasi baru untuk memecahan masalah-masalah yang ada di desa Padamara.

Taman jati di Desa Padamara memiliki potensi yang sangat baik jika dikembangkan menjadi wisata edukasi dengan menampilkan keindahan alam dan mengutamakan kebersihan lingkungan sehingga dapat memberikan manfaat dari segi ekonomis dan keindahan lingkungan. 
Melihat gambaran tersebut, maka sangat besar peluang untuk mengembangkan dan memasarkan desa wisata sebagai produk wisata Padamara untuk meningkatkan pemahaman masyarakat akan pentingnya desa wisata bagi peningkatan di sektor perekonomian secara keseluruhan. Untuk mengembangkan produk desa wisata di Padamara maka perlu dilakukan penataan dan manajemen lingkungan yang baik, serta pemahaman masyarakat akan pentingnya desa wisata harus lebih ditekankan, sehingga terciptanya Desa Wisata Padamara. Oleh karena itu diperlukan suatu pengembangan Potensi Eduwisata Melalui Tata Kelola Sumber Daya Alam Dan Lingkungan Di Desa Padamara Kecamatan Sukamulia Kabupaten Lombok Timur, NTB

\section{Metode}

Metode yang digunkan dalam kegiatan pengabdian ini adalah pelatihan, pendampingan dan pengembangan lingkungan sebagai eduwisata di Desa padamara, Sukamulia, Lombok Timur dengan melalui beberapa tahapan yaitu: tahap persiapan, tahap pelaksanaan, dan tahap evaluasi.

a. Persiapan

Persiapan rencana program pengabdian masyarakat di desa padamara dengan mekalukan kegiatan survey lapangan, izin ke kepala desa dan wawancara kepada penduduk setempat sebelum merumuskan program-program yang akan dilakukan. Lebih lanjut dilaksanakan Pengenalan wilayah, problem solving, survey terhadap masyarakat di Desa Tanjung Luar, melakukan kerjasama dengan instansiinstansi terkait di lingkup Desa Tanjung Luar. Menyiapkan bahan dan peralatan yang dibutuhkan selama pelaksanaan pengabdian.

b. Prosedur Pelaksanaan

Pada tahap pelaksanakan masyarakat dibagi menjadi 3 kelompok yang didampingi oleh tim pengabdian untuk melaksanakan program pengembangan berupa; 1) pengelolaan taman jati sebagai eduwisata berupa fasilitas belajar, bermain dan spot foto; 2) pengadaan taman baca dilingkungan taman jati ; 3) pemberdayaan ekonomi masyarakat dilingkungan taman jati.

c. Tahap Evaluasi

Pada tahap evaluasi ini, tim melakukan evaluasi terhadap proses pengembangan lingkusngan sebagai eduwisata dan dampaknya terhadap masyarakat. Evaluasi dilakukan ketika proses pendampingan dan hasil pengembagan yang berhasil dilakukan dan di lestarikan secara berkelanjutan.

\section{Hasil dan Pembahasan}

\section{Pengelolaan taman jati}

Penataan taman jati menjadi potensi eduwisata merupakan salah satu program utama dari team pengabdian. Secara umum taman adalah sebuah tempat yang terencana atau sengaja direncanakan yang dibuat untuk menampilkan keindahan dari berbagai tanaman dan bentuk alami. Adapun taman jati Padamara menampilkan keindahan alami dari pohon-pohon jati, sehingga masyarakat Desa Padamara dapat menikmati taman jati dengan suasana khas Desa Padamara yang memiki rasa kenyamanan tersendiri.

a. Persiapan

Penataan taman jati sebagai potensi eduwisata mendapat antusias yang positif dari warga desa. Tim pengabdian Bersama dengan kelompok masyarakat Desa Padamara melakukan diskusi pengembangan taman jati agar menjadi sebuah taman yang dapat bernilai eduwisata bagi para pengunjung. Adapun proses pngembangan yang dilaksanakan berupa; pembersihan taman jati, Pembuatan meja dan tempat duduk, pembuatan spot foto, pembuatan papan kratif, penanaman tanaman hias dari sayuran sawi, pembuatan pintu masuk dan pagar bintang, pengecatan meja, pembuatan berugak, pemasangan ayunan dari ban bekas dan ayuanan ikat (hammoxks) dan Perawatan kebun jati secara berkelanjutan. 


\section{b.Pelaksanaan}

Pelaksanaan ditargetkan selama dua minggu dan akan dilakukan pengoreksian atapun kelengkapan atribut yang diperlukan sesuai kebutuhan pada waktu yang tidak terjadwalkan. Setelah didapatkan hasil dari diskusi yang dilakukan, kemudian direalisasikan hasil diskusi yang telah disepakati.

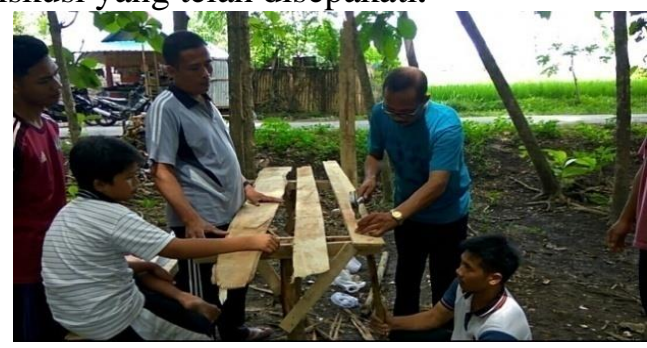

Proses pembuatan meja dan tempat duduk

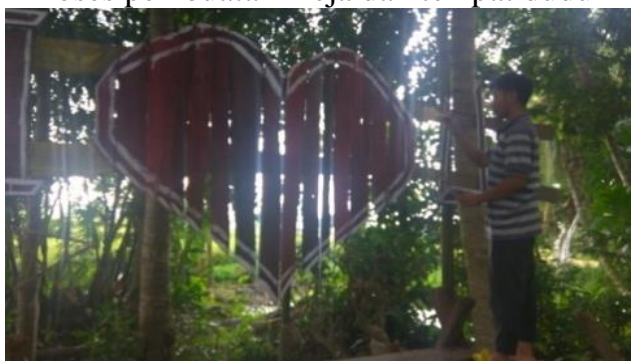

Pembuatan Spot Foto

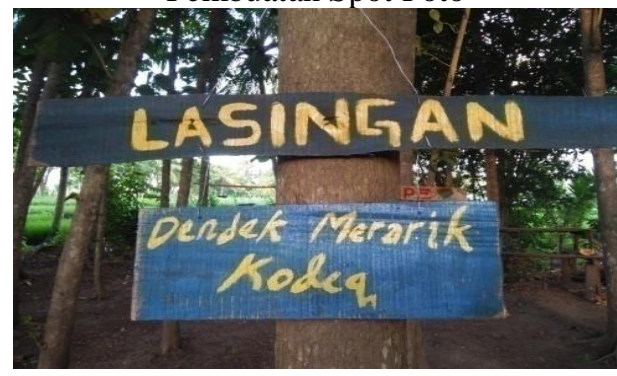

Pembuatan Papan kreatif

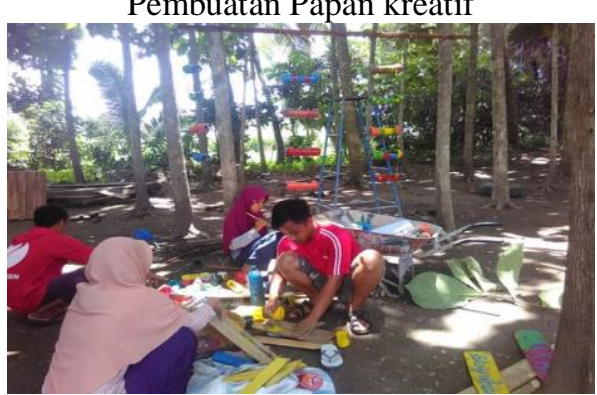

Proses penanaman tanaman hias

Perawatan dilakukan setiap hari yaitu waktu pagi dan sore perawatan berupa pembersihan sekitar taman jati dengan cara menyapu daun-daun yang jatuh kemudian dibakar di tempat yang sudah disediakan, selanjutnya penyiraman tanaman dilakukan setiap hari untuk mencegah tanaman yang sudah ditanam baik sawi atau tanaman hias tidak mati, perawatan dilakukan oleh teammpengabdian Bersama dengan masyarakat dengan cara membagi tugas, sebagian team bertugas menyapu dan sebagian lagi bertugas menyiram tanaman.

2. Pengadaan taman baca dan fasilitas Belajar Taman baca merupakan tempat sekumpulan koleksi buku yang dioperasikan oleh sekolompok orang serta dimanfaatkan oleh masyarakat untuk menggali informasi, menambah wawasan dan juga sebagai upaya untuk memelihara dan meningkatkan efisiensi dan efektifitas proses belajar-mengajar. Taman baca yang terorganisir secara baik dan sistematis, secara langsung atau pun tidak langsung dapat memberikan kemudahan bagi seluruh komponen masyarakat yang ingin menggali informasi ataupun ilmu pengetahuan yang lebih luas lagi. Taman baca yang dikembangkan berupa taman baca terintegrasi alam dengan kekhasan Desa Padamara, sehingga masyarakat tertarik untuk membaca ataupun mencari informasi sesuai yang dibutuhkan.

Lebih lanjut, selain taman baca terdapat les belajar yang dikembangkan dengan memanfaat potensi SDM yang ada d Desa padamara sebagai tutornya. Untuk menarik minat masyarakat agar berkunjung dan membaca di Taman Baca Padamara, Tim pengabdian melakukan sosialisasi ke masyarakat dan beberapa sekolah dasar yang ada di Desa Padamara. Sosialisasi ini dilakukan selama 6 hari dengan melakukan kunjungan ke tiga Sekolah Dasar yang ada di Desa Padamara, dengan 2 hari kunjungan untuk masing-masing sekolah. 


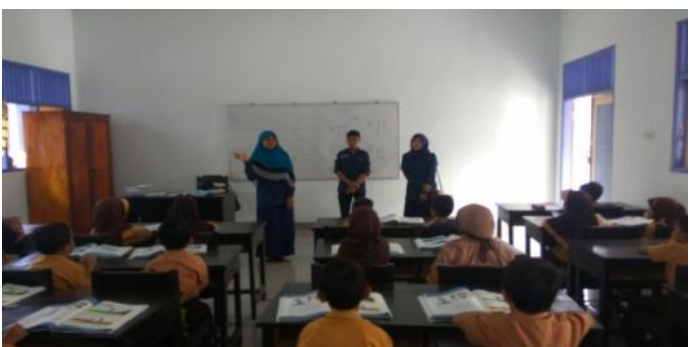

Sosialisasi Taman Baca

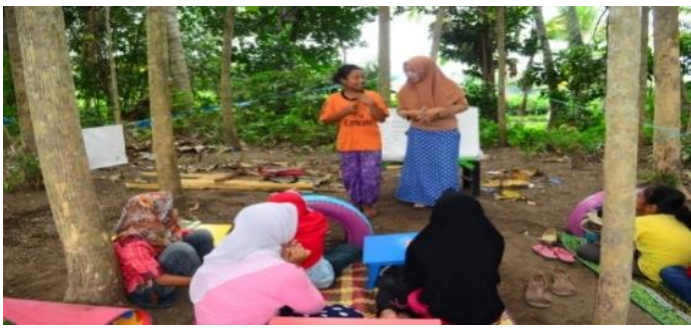

Les private terintegrasi alam

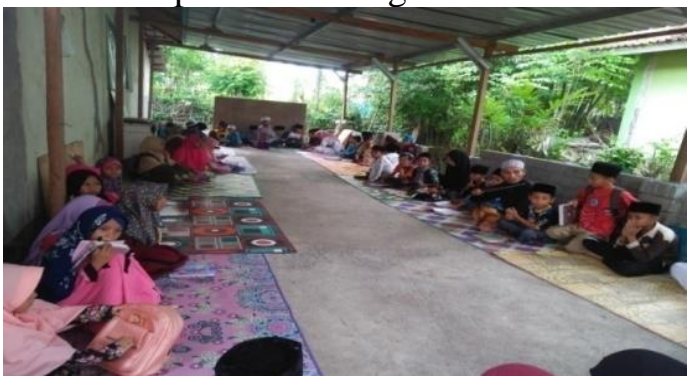

Kegiatan Belajar Qur'an

Hasil dari keterlaksanaan program ini dapat dilihat dari jumlah peserta les setiap pertemuan. Semakin bayak atau stabil pesertanya maka pelaksanaan program kerja ini dapat dikatakan berhasil.

\section{Pengembangan Budidaya Ikan}

Budidaya ikan merupakan suatu kegiatan atau usaha untuk memelihara ikan supaya tumbuh dengan baik sehingga medapat keuntungan secara ekonomis. Pada kegiatan pengabdian yang dilakukan salah satu program yang diprogramkan yaitu kegiatan budidaya ikan. Tahapan yang dilakukan pada kegiatan ini yaitu sosialisai pada warga desa Padamara terkait program tim pengabdian Desa Padamara kepada warga Desa Padamara, kunjungan ke kadus setiap dusun, penempatan lokasi budidaya ikan, pembersihan kolam dan pelepasan bibit ikan nila. a. Persiapan

Perkenalan program pengabdian kepada warga Desa Padamara. Sosialisai program kerja terkait budidaya ikan, dilaksanakan di kantor desa padamara yang dihadiri oleh Bapak Camat Sukamulia, Kepala desa Padamara, Babinsa Desa padamara, Polmas Desa Padamara, semua kadus dan beberapa masyarakat yang mewakili. Kegiatan ini berlangsung di aula kantor Desa Padamara.

Kunjungan Semua Kadus Se-desa Padamara. Desa Padamara memiliki lima dusun yang masing-masing dikepalai oleh satu Kadus, diatara 5 dusun tersebut yaitu Dusun Dayen Rurung di kepalai oleh L. Lanang Jati, Dusun Lauq Rurung di di kepalai oleh Lalu Opan. Dusun Dasan Tangar di kepalai oleh Rudi dan Dusun Dasan Baru. Pada kegiatan kunjungan tim pengabdian menyampaikan bahwa kami meminta ruang (kolam) yang akan kami lepaskan bibit ikan dan rawat selama kegitan KKN, kemudian kami akan wakafkan untuk dimanfaatkan sebesarbesarnya untuk kepentingan umum. Kami diberi empat lokasi yaitu 2 kolam ikan dan 2 sungai, yang kemudian melakukan pembersihan kolam dan pengadaan bibit.

b. Pelaksanaan

Pelaksanaan dimulai dari pembersihan kola ikan yang dilakukan selama 1 minggu, kolam ikan untuk kadus Dasan Tangar dan Dasan Baru dilakukan selama 2 hari, setelah dilakukan pembersihan kolam selama 2 hari kolam siap ditebarkan bibit ikan. Kolam yang dipeuntukan untuk Dusun Dayen Rurung, Dusun Timuk Rurung dan Dusun Lauk Rurung ditempatkan di satu dusu yaitu di Dusu Timuk Rurung tepatnya di kolam milik mamiq Anang. Kolam ini dibersihkan selama 2 hari yaitu pada hari Kamis dan Jum' at (28 Februari - 1 Maret 2019).

Alat dan bahan yang digunakan dalam kegiatan pembersihan kolam untuk budidaya ikan ini adalah: Sabit, Cangkul, Gareng, Parang dan lain-lain.Pembersihan dilakukan dengan mengangkat lumpurlumpur dan sampah-sampah yang berupa dedaunan tumbuhan kangkung dan 
tumbuhan semak menjalar lainnya yang harus dibersihkan supaya ikan yang dibudidayakan hidup dengan nyaman sehingga dalam proses pertumbuhanya menjadi lebih cepat atau optimal. Berikut gambar pembersihan kolam ikan:

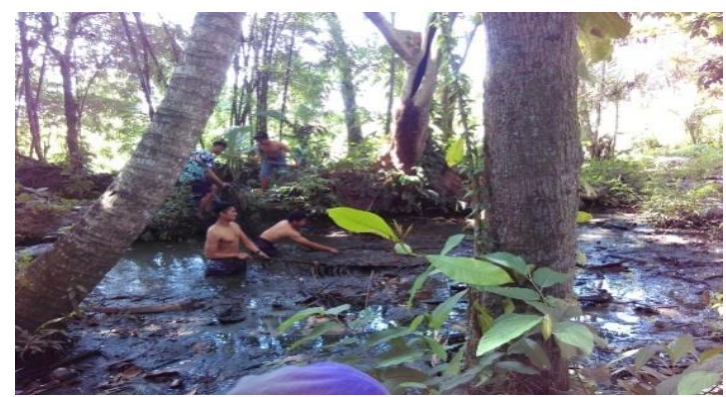

Pembersihan kolah ikan

Proses kedua ialah Penebaran Ikan, dilakukan pada hari Sabtu tanggal 2 Maret 2019. Bibit yang ditebar dibeli di BBI (Balai Benih Ikan) Lingsar. Penebaran ikan dilakukan pada sore hari, hal ini dilakukan untuk menghidari perubahan suhu yang drastis pada air kolam sehingga ikan yang ditebar tidak mengalami stres yang kemudian berujung pada kematian ikan secara masal. Ikan yang ditebar ada 2 jenis yaitu ikan nila dan ikan mas. Pemilihan jenis ikan ini dilakukan karena lokasi kolam yang terletak di area perairan tawar. Sebelum dilakukan penebaran ikan, diadakan serah terima bibit ikan secara simbolis oleh masing-masing pengelola ikan. Penebaran bibit ikan dapat dilihat pada gambar dibawah ini:

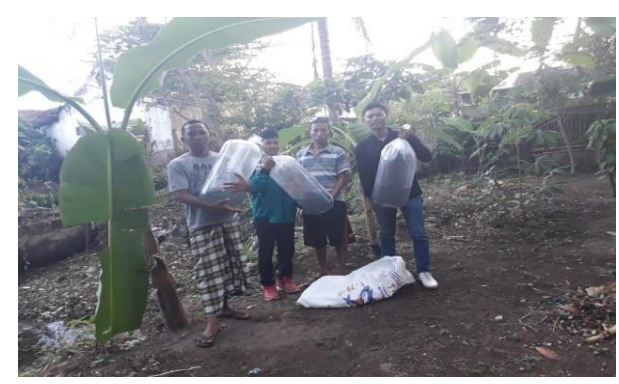

Serah Terima Bibit Ikan

c. Tujuan

Dengan adanya pelaksanaan program ini masyarakat dapat mengetahui cara membudidayakan ikan dengan media yang mudah dijangkau oleh masyarakat, sehingga diharapkan nantinya masyarakat Padamara dapat memiliki alternatif mata pencaharian yang lain.

d. Evaluasi

Untuk program budidaya ikan pada kolam warga Padamara ini dapat dikatakan berhasil karena tidak ada kendala dalam pelaksanaan kegiatan yang dilakukan

\section{Kesimpulan}

Pengabdian mengenai pengembangan potensi dduwisata melalui tata kelola sumber daya alam dan lingkungan di Desa Padamara Kecamatan Sukamulia Kabupaten Lombok Timur, NTB dilaksanakan selama 45 hari di Desa Padamara Kecamatan Sukamulia dengan program utama yaitu Wisata Taman Jati, Taman Baca dan bimbingan belajar, pemberdayaan ekonomi masyarakat berupa Budidaya Ikan. Program tersebut menghasilkan dampak positif yaitu meningkatnya kualitas sumber daya manusia dan ekonomi masyarakat yang ada di Desa Padamara. Dengan adanya program-program tersebut diharapkan masyarakat mendapatkan pengetahuan dan wawasan sehingga dapat dimanfaatkan dalam kehidupan sehari-hari dilingkungan masyarakat desa

\section{Ucapan Terima Kasih}

Terimakasih kepada dosen pengampu mata kuliah Studi Mandiri Drs. Dr. Abdul Syukur, M.Si dan Dr. Jamaluddin, M.Pd., yang telah membimbing kami dalam proses penyusunan paper pengabdian ini yang dilakukan di Ponpes AlIstiqomah telagawaru dan terimakasih kepada pihak yang terlibat serta memberi dukungan atas terlaksananya kegiatan pelatihan ini.

\section{Daftar Pustaka}

Adi. L. P., Thatok. A., Harmi. W dan Hilmiati.. 2018. Identifikasi Desa Wisata Di Kecamatan Jerowaru, Kabupaten Lombok Timur. Jurnal Parawisata Terapan. Vol. 2(1) 33-35.

Angga. H. D. 2017. Pengembangan Obyek Dan Dan Daya Tarik Wisata Alam Sebagai Daerah Tujuan Wisata Di Kabupaten 
Karanganyer. Jurnal Sosiologi DILEMA. Vol. 32(1) 34-44. ISSN : 0215/9635.

Ati. S. S. 2017. Pengembangan TBM Sebagai Sarana Meningkatkan Minat Baca Masyarakat. Jurnal ANUVA. Vol. 1(1) 1932. ISSN: $2598 / 3040$.

Cempaka. O. J., Yuniwati., Yuli. S. 2013. Peran Taman Baca Masyarakat Dalam Menumbuhkan Minat Baca Anak Di Taman Baca Masyarakat "MORTIR" Banyumanik-Semarang. Jurnal Ilmu Perpustakaan. Vol. 2(2). 1-10.

Ferdinan. Y., Mochamad. M., Heru. R. 1013. Pengembangan Wisata Alam Berbasis Ekowisata Dalam Perspektif Pelayanan Publik (Studi pada Disparjuk Kabupaten Ngajuk). Jurnal Admistrasi Publik (JAP). Vol. 3 (12) 2123-2127.

Hidat Marceilla. 2011. Strategi Perencanaan dan Pengembangan Objek Wisata (Studi Kasus Pantai Pangandaran Kabupaten Ciamis Jawa Barat). Jurnal Tourism and Hospitality Essentials. Vol. 1(1).

Hijriati Emma dan Ria. M. 2014. Pengaruh Ekowisata Berbasis Masyarakat Terhadap Perubahan Kondisi Ekologi, Sosial dan Ekonomi di Kampung Batu Suhunan, Sukabumi. Juenal Sosial Pedesaan. Vol. 2(3). ISSN. 2302-7517.

Lasabuda Ridwan. 2013. Pembangunan Wilayah Pesisir Dan Lautan Dalam Perspektif Negara Kelautan Republik Indonesia. Jurnal Ilmiah Platax. Vol. 1-2. ISSN: 2302-3589.

Lestari Gina. 2015. Bhinneka Tunggal Ika: Khasanah Multi Kultural Indonesia Di Tengah Kehidupan Sara. Jurnal Pendidikan Pancasila dan Kewarganegaraan. Program Studi Ketahanan Nasional Universitas Gajah Mada. Vol: 28 (1).

Petrus. B. S. 2012. Pengembangan Taman Baca Masyarakat Sebagai Sumber Belajar. Jurnal Ilmu VISI P2TK PAUD NI. Vol. 7(1) 42-56. 